\title{
Serum Human Epididymal Protein 4 is Associated with Depressive Symptoms in Patients with Chronic Obstructive Pulmonary Disease [Retraction]
}

Shu Y, Wang W. Int J Chron Obstruct Pulmon Dis. 2020;15:3417-3422.

The Editor-in-chief and Publisher of International Journal of Chronic Obstructive Pulmonary Disease wish to retract the published article. Concerns were raised to us by the The Irish Longitudinal Study on Ageing (TILDA) investigation team. TILDA did not measure the biomarker human epididymis protein 4 (HE4) or disaggregate data on lung disease sufficiently to identify COPD as reported in the article. Thus, the observations and findings reported in the study were not supported by the TILDA dataset.
Despite several attempts, the authors could not be contacted for an explanation and the decision was made to retract the article.

Our decision-making was informed by our policy on publishing ethics and integrity and the COPE guidelines on retraction.

The retracted article will remain online to maintain the scholarly record, but it will be digitally watermarked on each page as "Retracted".

\section{Publish your work in this journal}

The International Journal of COPD is an international, peer-reviewed journal of therapeutics and pharmacology focusing on concise rapid reporting of clinical studies and reviews in COPD. Special focus is given to the pathophysiological processes underlying the disease, intervention programs, patient focused education, and self managemen protocols. This journal is indexed on PubMed Central, MedLine and CAS. The manuscript management system is completely online and includes a very quick and fair peer-review system, which is all easy to use. Visit http://www.dovepress.com/testimonials.php to read real quotes from published authors. 